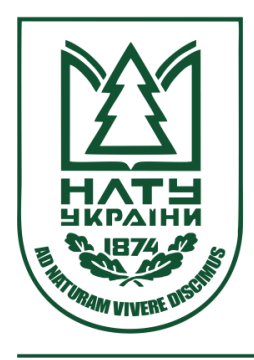

Науковий вісник НЛТУ України Scientific Bulletin of UNFU

https://nv.nltu.edu.ua

https://doi.org/10.36930/40310402

$@ \bowtie$ Correspondence author

Article received 27.07.2021 p.

Article accepted 09.09.2021 p.

I. A. Chemerys

UDC 502.211:[630*1:582.475.1:581.1](477.46)

I. А. Чемерис, С. І. Ключка

Черкаський державний технологічний університет, м. Черкаси, Украйна

\title{
ВМІСТ ФОТОСИНТЕТИЧНИХ ПІГМЕНТІВ У ХВОЇ СОСНИ ЗВИЧАЙНОЇ (PINUS SYLVESTRIS L.) В УМОВАХ ЗАПОВІДНИХ ОБ'ЄКТІВ МІСТА ЧЕРКАСИ
}

Деревні насадження парків міст, що належать до природно-заповідного фонду держави, перебувають під впливом стресових чинників, тому $є$ актуальним питання їх діагностики. Фотосинтетичний апарат рослин $є$ одним 3 показників їх життєвого стану. Досліджено фотосинтетичний апарат хвої сосни звичайної парків-пам'яток садово-паркового мистецтва Черкас. Встановлено, що в Черкасах поєднання перепадів температури та збільшення середньої літньої температури і зниження відносної вологості повітря створює умови для посух. Високий рівень забруднення атмосферного повітря (індекс забруднення 7,22) у поєднанні з низьким потенціалом до розсіювання шкідливих домішок в атмосфері сприяють послабленню соснових деревостанів парків міста. Виявлено збільшення концентрації хлорофілів та каротиноїдів хвої порівняно $з$ деревами контрольної ділянки у парках "Сосновий бір" (Ахл $a$ - в 1,2 раза; Ахл $b$ - в 1,6 раза; Акар - в 1,3 раза) та "Обласна лікарня" (Ахл $a$ - в 1,4 раза; Ахл $b$ - в 1,9 раза; Акар - в 1,4 раза), а у дерев парку "Перша міська лікарня" встановлено, що концентрація хлорофілу $a$ та каротиноїдів в 1,5 раза, а хлорофілу $b$ в 1,05 раза менша, ніж у контрольних дерев. Виявлено достовірний зворотній зв'язок між концентрацією сульфатів у снігових опадах та концентрацією хлорофілу $a\left(r=-0,844\right.$ при $t_{s}=$ $\left.6,24>t_{0,05}=2,26\right)$ та хлорофілу $b\left(r=-0,762\right.$ при $\left.t_{s}=5,37>t_{0,05}=2,26\right)$. З'ясовано, що співвідношення вмісту хлорофілу $a$ до хлорофілу $b$ у досліджуваних дерев нижче $(2,50-2,59)$ порівняно 3 контрольними деревами $(3,52)$. Виявлено, що співвідношення вмісту хлорофілів до вмісту каротиноїдів у дерев контрольної ділянки $(4,09)$ менше, ніж у дерев паркових насаджень $(4,21-4,53)$. З'ясовано, що фотохімічна активність хлоропластів соснових деревостанів досліджуваних ділянок нижча порівняно 3 контролем $\left(425,84^{ \pm 18,24}\right)$ : парк "Сосновий бір" - 386,44 ${ }^{ \pm 15,63,}$ парк "Обласна лікарня" - 354,26 $6^{ \pm 12,34}$, парк "Перша міська лікарня" - 300,01 $\pm 13,85$. Встановлено, що зміни фотосинтетичного апарату рослин парків "Сосновий бір" та "Обласна лікарня" свідчать про розвиток адаптивної специфічної реакції на стресогенні чинники міського середовища, а зниження всіх досліджуваних показників сосни звичайної "Парку Першої міської лікарні" діагностує пригнічення фотосинтетичної функції деревостанів та розвиток деструктивних процесів.

Ключові слова: міські насадження; метеорологічні чинники; концентрації фотосинтетичних пігментів; фотохімічна активність хлоропластів; соснові деревостани.

\section{Вступ / Introduction}

Зелені насадження міста формують сприятливе середовище урбанізованих територій. Рівень озеленення міст $\epsilon$ одним 3 показників, що визначають комфортність урбоекосистеми. Міські насадження виконують низку важливих функцій, зокрема: меліоративні, інженерно-захисні, рекреаційні, санітарно-гігієнічні, етико-естетичні, архітектурно-планувальні.

Місто Черкаси є одним з небагатьох обласних центрів, на території якого збереглася частина лісового масиву "Черкаський бір". Вважають, що Черкаський бір був лівим берегом основного русла або рукава Дніпра. Розташований лісовий масив у межах другої піщаної (борової) тераси річки Дніпро, яка піднесена над лучною терасою на 8-10 м. Вона ніколи не заливається весняними водами, $є$ хвилясто-горбистою або дюнною і поступово підвищується над рівнем болота Ірдинь на
50 м. Найбільш підвищена частина бору розташована на другій давній боровій терасі, яка є більш пласкою i дюнний рельєф її слабко виражений. Тут переважають дубово-соснові ліси 3 незначною домішкою грабово-дубово-соснових і соснових лісів $[6,28]$. Черкаський бір є найпівденнішою межею природного поширення наддніпрянських хвойних лісів в Україні.

У межах міста паркову зону на території Черкаського бору утворюють такі об'єкти природно-заповідного фонду: парк-пам'ятка садово-паркового мистецтва загальнодержавного значення "Сосновий бір" (створено у 1977 р., загальною площею 39 га), парки-пам'ятки садово-паркового мистецтва місцевого значення "Парк обласної лікарні" (створено у 1972 р., загальною площею 21 га) та "Парк Першої міської лікарні" (створено у 1972 р., загальною площею 13 га) (Pryrodno-zapovidnyi). Деревостани парків у першому ярусі мають сосну, в другому - дуб, граб, липу, березу, осику. Середній вік

Інформація про авторів:

Чемерис Інгріда Альгімантівна, канд. біол. наук, доцент, завідувач кафедри загальної екології, педагогіки та психології. Email: ichemerys@ukr.net; https://orcid.org/0000-0002-0664-8508

Ключка Світлана Іванівна, канд. пед. наук, доцент, кафедра загальної екології, педагогіки та психології. Email: svitkl@ukr.net; https://orcid.org/0000-0001-5702-6840

Цитування за ДСТУ: Чемерис І. А., Ключка С. І. Вміст фотосинтетичних пігментів у хвої сосни звичайної (Pinus sy/vestris L.) в умовах заповідних об'єктів міста Черкаси. Науковий вісник НлтУ України. 2021, т. 31, № 4. С. 15-21.

Citation APA: Chemerys, I. A., \& Kliuchka, S. I. (2021). Content of photosynthetic pigments in Pinus sylvestris L. in the conditions of Cherkasy reserved objects. Scientific Bulletin of UNFU, 31(4), 15-21. https://doi.org/10.36930/40310402 
насаджень сосни - 64 роки, дуба - 81 рік. Вплив міських умов заповідних об'єктів призвів до спрощення загальної структури деревостанів.

До негативних чинників, які є стресовими для міських насаджень, належать нестача вологи, підвищена температура, рекреаційні навантаження, вплив різноманітних забруднювачів. Серед хвойних дерев одним з видів із найнижчою стійкістю до таких стресогенних чинників є сосна звичайна (Pinus sylvestris L.) $[14,30]$, яка $\epsilon$ панівною породою міських парків. Сьогодні відбувається масове всихання соснових насаджень на території Черкаського бору, а за міських умов заповідних об'єктів процеси деградації деревостану посилюються. За таких умов важливим завданням $\epsilon$ об'єктивне оцінювання стану соснових деревостанів, а саме оцінювання адаптаційних реакцій на вплив абіотичних стресових чинників, таких як нестача вологи, зміна температурного режиму, інтенсивність освітлення, забруднення атмосферного повітря, склад грунту (засоленість, концентрація токсичних сполук, зокрема важких металів) [32].

Одним із показників, що характеризує життєвий потенціал рослин, є стан їх фотосинтетичного апарату, оскільки оптимальне функціонування асиміляційного апарату рослин забезпечує їх стійкість. Дослідження стану фотосинтетичного апарату деревостанів об'єктів природно-заповідного фонду в Черкасах не здійснювали, тому наше дослідження є актуальним і дає змогу оцінити невидимі пошкодження рослин, які настають внаслідок хронічної дії абіогенних стресорів. Цю ознаку можна використовувати для ранньої діагностики стану лісових екосистем, які перебувають у зоні впливу як антропогенних, так і неантропогенних впливів.

Об'єкт дослідження - сосна звичайна в умовах урбанізованої екосистеми.

Предмет дослідження - фотосинтетичний апарат хвої сосни звичайної.

Мета роботи - з'ясувати адаптаційну стійкість соснових деревостанів за умов дії стресових чинників міської екосистеми.

Для досягнення зазначеної мети визначено такі основні завдання дослідження:

- проаналізувати динаміку рівня атмосферного забруднення у Черкасах та несприятливих для соснових деревостанів погодних явищ у районах дослідження;

- діагностувати стан соснових насаджень урбоекосистеми на основі вивчення концентрацій фотосинтетичних пігментів у хвої сосни звичайної, їх співвідношення; проаналізувати фотохімічну активність хлоропластів.

Одним із показників фотохімічної активності хлоропластів $є$ реакція Хілла. Це комплекс початкових стадій фотосинтезу, в яких мобілізовані з води електрони спрямовуються на відновлення введених у реакційну суміш акцепторів електронів [26]. Реакція Хілла $є$ моделлю первинних реакцій фотосинтезу і характеризує загальний стан фотосинтетичного апарата рослин. Але варто зазначити, що реакцію Хілла часто використовують для діагностики продуктивності сільськогосподарських рослин [7, 17, 34], у деяких дослідженнях фотохімічну активність хлоропластів використовують для вивчення стійкості рослин за міських умов антропогенних впливів [32].

Наукова новизна отриманих результатів дослідження - вперше для умов Черкас визначено адаптаційну стійкість соснових деревостанів за станом фотосинтетичного апарату, зокрема і вивчення фотохімічної ак- тивності хлоропластів за умов дії стресових чинників міської екосистеми.

Практична значущість результатів дослідження виконаний аналіз дає змогу забезпечити комплексний та збалансований підхід до ведення паркового господарства і формування оптимальних умов для збереження соснових деревостанів за міських умов.

Аналіз останніх досліджень та публікацій. Фотосинтетичний апарат $є$ однією з найчутливіших до абіотичних стресорів систем клітини. Встановлено, що стресори абіотичного походження зумовлюють зміни у вмісті фотосинтетичних пігментів, їх співвідношенні та змінюють фотосинтетичну активність хлоропластів [3, $5,14]$. Треба зазначити, що недостатня адаптивність фотосинтетичного апарату до несприятливих умов середовища знижує не тільки життєвість, а і продуктивність рослин [2]. Відомо, що за умов заповідних об'єктів міста зменшується вміст хлорофілів $a$ i $b$, а вміст каротиноїдів збільшується [4, 11, 33].

Вміст пігментів характеризує потенційну фотосинтетичну здатність рослин й існує зв'язок між вмістом пігментів і зниженням стійкості рослин. Вищий вміст хлорофілу $a \epsilon$ показником високої потенційної інтенсивності фотосинтезу. Однією 3 причин руйнування хлорофілу є активація полютантами перекисного окислення ліпідів біологічних мембран хлоропластів. Чутливішим до дії аеротоксикантів $\epsilon$ хлорофіл $a$, каротини, а менш чутливим - хлорофіл $b$ [14]. Так, реакція фотосинтетичного апарату на оксид сірки (IV) проходить в три фази: незначне пригнічення, активація і подальше пригнічення [31]. Аерополютанти нагромаджуються у хлоропластах, що змінює їх структуру $[14,15,31]$, тому пригнічується фотосинтез, руйнуються пігменти і хлорофіл перетворюються на феофітин [15], також знижується синтез хлорофілу. Саме оксид сірки (IV) вважають фотосинтетичним отрутою [15, 31]. Невисокі концентрації токсичних газів спричиняють повільне зниження інтенсивності фотосинтезу, оскільки вони пригнічують процес формування хлоропластів, біосинтез пігментів і їх функціональну активність, а високі швидке пригнічення фотосинтезу.

Питання біофізичних, біохімічних, фізіологічних, біофізичних та екологічних аспектів фотосинтезу грунтовно вивчили вчені. Питання дослідження стійкості фотосинтетичного апарата до стресів $є$ актуальним, про що свідчить низка публікацій $[8,10,16,20,21,22,25$, $36]$, але на регіональному рівні питання реакції фотосинтетичного апарату на абіогенні стресори недостатньо вивчене.

Матеріали та методи дослідження. Дослідження фотосинтетичного апарату проводили у хвої другого року життя дерев Pinus sylvestris L. Середній вік досліджених дерев у парку "Сосновий бір" становив 60 років, середня висота -21 м, середній діаметр - 28 см, повнота деревостану - 0,5; у "Парку обласної лікарні" середній вік дерев становив 68 років, середня висота 23 м, середній діаметр - 32 см, повнота деревостану 0,4; у "Парку Першої міської лікарні" середній вік дерев становив 70 років, середня висота - 24 м, середній діаметр - 33 см, повнота деревостану - 0,2. Проби рослинного матеріалу (хвою) відбирали у серпні 2020 р. у районах дослідження: парку-пам'ятці садово-паркового мистецтва загальнодержавного значення "Сосновий бір", парках-пам'ятках садово-паркового мистецтва міс- 
цевого значення "Парк обласної лікарні", "Парк Першої міської лікарні", розташованих у межах Черкас та на контрольній ділянці, яка розміщена у лісовому масиві "Черкаський бір" у зоні мінімального антропогенного навантаження. Кількість модельних дерев становила десять 3 кожного району дослідження. Проби відбирали на висоті 2 м з нижньої частини крони зі східної сторони.

Вміст хлорофілів визначали у $100 \%$ ацетоні за допомогою методу Холм-Веттштейна [26]. Для цього наважку рослинного матеріалу (100-200 г) за наявності $\mathrm{MgCO}_{3}$ розтирали та екстрагували $100 \%$ ацетоном. Отриманий екстракт пропускали через колбу Бунзена, виливали в мірну колбу об'ємом 25 мл. Доводили до мітки ацетоном і використовували для спектрофотометричного визначення (Specord 210 Plus) оптичної щільності за різних довжин хвиль: для хлорофілів $a$ i $b-644 \mathrm{i}$ $662 \mathrm{нм}$, для каротиноїдів - 440,5 нм. Основою розрахунку концентрацій пігментів хлоропластів були формули Веттштейна для 100 \% ацетону:

$$
\begin{gathered}
C_{\text {chl.a }}=9,784 \cdot D_{662}-0,990 \cdot D_{644} ; \\
C_{\text {chl. } b}=21,426 \cdot D_{644}-4,650 \cdot D_{662} ; \\
C_{\text {chl. }}+C_{\text {chl. } b}=5,134 \cdot D_{662}+20,436 \cdot D_{644} ; \\
C_{\text {car }}=4,695 \cdot D_{440,5}-0,268 \cdot\left(C_{\text {chl. } a}+C_{\text {chl. }} b\right),
\end{gathered}
$$

де: $C$ - концентрація хлорофілів $a, b$ і каротиноїдів, мг/л, $D$ - оптична густина в центрах поглинання пігментів 440,5; 644 і 662 нм. Вміст пігментів розраховували за такою формулою:

$$
A=\frac{C \cdot V}{H \cdot 1000},
$$

де: $A$ - вміст пігменту в мг на 1 г сирої наважки; $C$ концентрація пігменту в мг/л після розрахунку за наведеними вище формулами; $V$ - об'єм екстракту, мл (25 мл); $H$ - маса рослинного матеріалу, г.

Для визначення фотохімічної активності хлоропластів наважку хвої (2 г) гомогенізували у середовищі виділення $(0,3 \mathrm{M} \mathrm{NaCl}$ у $0,6 \mathrm{M}$ фосфатному буфері, $\mathrm{pH}$ $6,9)$. Методом диференціального центрифугування з гомогенату виділили суспензію хлоропластів. Реакцію Хілла вивчали в реакційній суміші, яка мала такий склад: 2,85 мл середовища виділення; 0,15 мл 0,1 М $\mathrm{MgCl}_{2} ; 1$ мл 7,5 мМ K $3 \mathrm{Fe}(\mathrm{CN})_{6}, 1$ мл суспензії хлоропластів. Три пробірки поміщали у темряву, а три - освітлювали впродовж 5 хв. Потім у проби (спочатку у світлові, потім у темнові) додавали по 1 мл $20 \%$-го розчину трихлороцтової кислоти та 2 мл $1 \mathrm{M}$ розчину $\mathrm{CH}_{3} \mathrm{COONa}$. Спектрофотометрично вимірювали оптичну густину розчинів за довжини хвилі 420 нм (контроль - вода). Для визначення хлорофілу у суспензії хлоропластів вимірювали оптичну густину профільтрованої суміші (об'ємом 10 мл) з 1 мл суспензії, 1 мл дистильованої води та $100 \%$-го розчину ацетону за довжини хвилі 652 нм. Фотохімічну активність хлоропластів (ФА) обчислювали за такою формулою:

$$
\Phi A=\frac{D_{420 \text { mемр. }}-D_{420 \text { світл. }} \cdot 60 \cdot 8}{1,04 \cdot 5 \cdot 0,29 \cdot D_{652}} .
$$

Проби снігу проаналізували на вміст основних йонів сольового складу, які є характерними для забруднювачів Черкас, а саме, $\mathrm{SO}_{4}{ }^{2-}, \mathrm{NH}_{4}{ }^{+}, \mathrm{NO}_{3}{ }^{-}$та $\mathrm{pH}$ згідно зі стандартними методиками їх визначення. Показник $\mathrm{pH}$ вимірювали електрометричним методом за допомогою приладу рН-150 [Rukovodstvo po kontroliu zahriaznenyia atmosfery, 1991]. Усі експерименти проводили тричі. Результати виражаються як середні значення \pm SE. Достовірність різниці оцінювали за допомогою ANOVA.

\section{Результати дослідження та їх обговорення / Research results and their discussion}

Одним 3 несприятливих явищ останніми роками $\epsilon$ посуха. Посуха $\epsilon$ природним явищем, яке зумовлене циркуляційними процесами в атмосфері, із тривалою відсутністю опадів (або значним їх зменшенням порівняно із середніми багаторічними показниками) у поєднанні з підвищеними температурами повітря і грунту та вітрами [1]. Варто зазначити, що поєднання посух 3

\begin{tabular}{|c|c|c|c|c|c|c|}
\hline Метеорологічні умови & $2015 \mathrm{p}$. & $2016 \mathrm{p}$. & $2017 \mathrm{p}$. & $2018 \mathrm{p}$. & $2019 \mathrm{p}$. & $2020 \mathrm{p}$. \\
\hline $\begin{array}{c}\text { Середня температура, }{ }^{\circ} \mathrm{C} \\
\text { зима } \\
\text { весна } \\
\text { літо } \\
\text { осінь } \\
\end{array}$ & $\begin{array}{c}-3,25 \\
+9,9 \\
+20,6 \\
+10,2\end{array}$ & $\begin{array}{c}-1,2 \\
+10,5 \\
+21,0 \\
+7,6\end{array}$ & $\begin{array}{c}-3,7 \\
+10,1 \\
+21,1 \\
+9,4\end{array}$ & $\begin{array}{c}-1,1 \\
+9,3 \\
+21,3 \\
+8,7\end{array}$ & $\begin{array}{c}-2,5 \\
+10,4 \\
+21,3 \\
+10,1\end{array}$ & $\begin{array}{c}+1,6 \\
+9,4 \\
+21,4 \\
+11,2\end{array}$ \\
\hline $\begin{array}{c}\text { Відносна вологість повітря, \% } \\
\text { зима } \\
\text { весна } \\
\text { літо } \\
\text { осінь }\end{array}$ & $\begin{array}{l}85 \\
65 \\
60 \\
79\end{array}$ & $\begin{array}{l}91 \\
73 \\
68 \\
82\end{array}$ & $\begin{array}{l}77 \\
76 \\
76 \\
79\end{array}$ & $\begin{array}{l}93 \\
70 \\
69 \\
81\end{array}$ & $\begin{array}{l}91 \\
71 \\
68 \\
76\end{array}$ & $\begin{array}{l}85 \\
62 \\
64 \\
76\end{array}$ \\
\hline $\begin{array}{c}\text { Абсолютний мінімум температури } \\
\text { у квітні-травні, }{ }^{\circ} \mathrm{C}\end{array}$ & $-2,8$ & $-0,5$ & $-2,4$ & $+5,2$ & $-5,4$ & $-9,7$ \\
\hline $\begin{array}{c}\text { Абсолютний мінімум температури } \\
\text { у вересні-жовтні, }{ }^{\circ} \mathrm{C}\end{array}$ & $-8,8$ & $-5,7$ & $-4,2$ & $-0,8$ & $-8,8$ & $-1,2$ \\
\hline $\begin{array}{c}\text { Середня кількість опадів, мм } \\
\text { зима } \\
\text { весна } \\
\text { літо } \\
\text { осінь } \\
\end{array}$ & $\begin{array}{l}22,3 \\
53,7 \\
61,1 \\
27,0 \\
\end{array}$ & $\begin{array}{l}47,8 \\
66,3 \\
63,6 \\
59,1 \\
\end{array}$ & $\begin{array}{l}31,5 \\
15,4 \\
31,6 \\
34,6 \\
\end{array}$ & $\begin{array}{l}69,7 \\
42,6 \\
64,3 \\
54,7 \\
\end{array}$ & $\begin{array}{l}49,4 \\
26,8 \\
17,7 \\
15,3\end{array}$ & $\begin{array}{l}34,6 \\
36,0 \\
32,9 \\
19,9\end{array}$ \\
\hline $\begin{array}{c}\text { Середня швидкість вітру, м/с } \\
\text { зима } \\
\text { весна } \\
\text { літо } \\
\text { осінь }\end{array}$ & $\begin{array}{l}3,1 \\
3,7 \\
2,8 \\
2,9\end{array}$ & $\begin{array}{l}3,7 \\
3,3 \\
2,8 \\
3,1\end{array}$ & $\begin{array}{l}3,7 \\
3,8 \\
3,0 \\
3,5\end{array}$ & $\begin{array}{l}3,4 \\
3,7 \\
2,6 \\
2,5\end{array}$ & $\begin{array}{l}3,3 \\
3,1 \\
2,7 \\
2,8\end{array}$ & $\begin{array}{l}3,0 \\
2,6 \\
2,7 \\
2,6\end{array}$ \\
\hline
\end{tabular}
антропогенним навантаженням в умовах міста призводить до швидкого послаблення міських насаджень та їх поступової деградації.

Табл. 1. Метеорологічні умови для Черкас (за даними Черкасыкого обласного центру з гідрометеорології)/ Meteorological conditions in Cherkasy (according to the Cherkasy Regional Center for Hydrometeorology) 
Також потрібно враховувати інверсії, які спричиняють збільшення концентрацій забруднювачів в атмосферному повітрі. За даними Черкаського обласного центру з гідрометеорології, для Черкас найбільшу кількість приземних інверсій спостерігають у нічні часи 3 квітня по жовтень (з максимумом у вересні), менша кількість вранці (у вересні та жовтні), вдень - взимку (січень, грудень), ввечері - $з$ серпня по жовтень. А найбільшу кількість припіднятих інверсій у нижньому двокілометровому шарі спостерігають у холодну частину року (iз жовтня-листопада по березень).

Результати аналізу метеорологічних умов для Черкас упродовж останніх шести років наведено у табл. 1. Згідно з їі даними, упродовж 2015-2020 pp. середня літня температура підвищилась на $0,8{ }^{\circ} \mathrm{C}\left(\right.$ від $+20,6^{\circ} \mathrm{C}$ у 2015 р. до $+21,4{ }^{\circ} \mathrm{C}$ у 2020 р.). Середня зимова температура має поліноміальну лінію тренду, що свідчить про коливання даних (рис. 1).

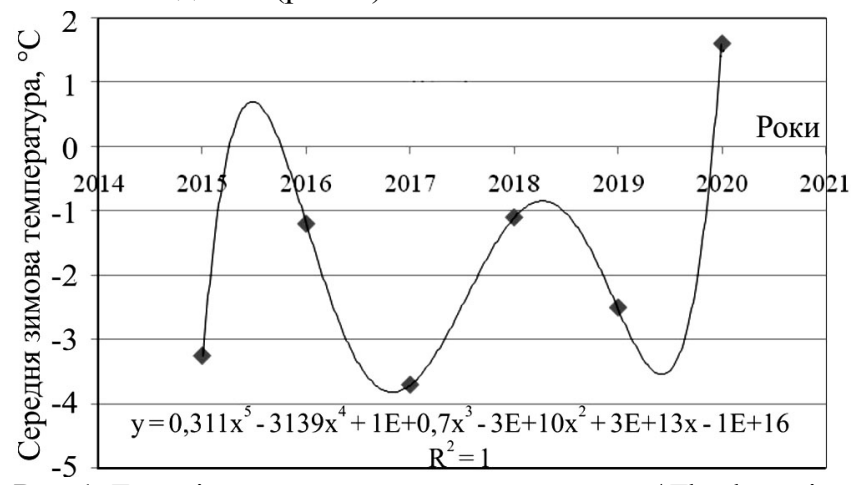

Рис. 1. Динаміка середньої зимової температури / The dynamics of the average winter temperature

Середня весняна температура змінюється в незначних межах: 9, $9^{ \pm 0,2}{ }^{\circ} \mathrm{C}$ (коефіцієнт варіації 5,04), а коливання середньої осінньої температури мають більший діапазон: 9, $5^{ \pm 0,5}{ }^{\circ} \mathrm{C}$ (коефіцієнт варіації 13,26). За результатами аналізу відносної вологості повітря з'ясовано, що впродовж останніх трьох років знижується відносна вологість повітря в усі сезони: взимку та навесні - на $8 \%$, влітку та восени - на $5 \%$. Абсолютний мінімум температури останні два роки у квітні-травні становив $-5,4{ }^{\circ} \mathrm{C}$ та $-9,7{ }^{\circ} \mathrm{C}$, а у вересні-жовтні $--8,8^{\circ} \mathrm{C}$ та $1,2{ }^{\circ} \mathrm{C}$. Максимальну температуру більшу за $25{ }^{\circ} \mathrm{C}$ понад 30 днів зафіксували для Черкас у червні 2020, 2019 рр. та серпні 2018 р. Середня кількість опадів також має поліноміальний тренд, але варто зазначити, що впродовж 2019 р., окрім зими, зафіксовано зниження кількості опадів, порівняно із середніми даними за роки дослідження, на 16 мм навесні, на 33 мм - влітку та на 23,8 мм - восени. За результатами аналізу середньої швидкості вітру з'ясовано, що восени та влітку вона нижча (середні значення за періоди дослідження 2,90 та 2,77 м/с відповідно), ніж взимку та навесні (середні значення 3,37 м/c). Тому Черкаси мають низький потенціал до розсіювання шкідливих домішок в атмосфері. Це переважання слабо вітряної погоди, часті тумани в осінній та весняний періоди року та мала кількість опадів влітку в поєднанні з безвітряною погодою [9].

Отже, середня літня температура має тенденцію до підвищення, весняна температура є стабільною, а зимова та осіння температура мають поліноміальний тренд, такий самий тренд має середня кількість опадів, хоча в окремі роки фіксували ії зниження. Поєднання коливань температури та збільшення середньої літньої тем- ператури і зниження відносної вологості повітря створює умови для посух, які послаблюють соснові деревостани.

Основними антропогенними джерелами забруднення атмосферного повітря у місті є підприємства паливно-енергетичного комплексу, хімічні підприємства та транспорт. Обсяг викидів забруднювальних речовин від автотранспорту знаходиться на рівні, а то і перевищує, обсяги викидів від підприємств. Тенденція зміни середнього рівня забруднення атмосферного повітря за останні п'ять років характеризувалася збільшенням за вмістом і оксиду азоту, аміаку та формальдегіду. За іншими домішками рівень забруднення не змінився. Щодо важких металів зменшення зафіксовано тільки для нікелю та хрому [29]. Проаналізувавши вміст забруднювальних речовин в атмосферному повітрі Черкас у 2019 р. (табл. 2), не виявлено перевищення середньодобових ГДК, але за оксидом вуглецю встановлено, що максимально разова ГДК перевищує середньорічний вміст у п'ять разів.

Табл. 2. Вміст забруднювальних речовин в атмосферному повітрі міста Черкаси [9] / The content of pollutants in the air of Cherkasy [9]

\begin{tabular}{|c|c|c|c|c|}
\hline $\begin{array}{c}\text { Назва забруд- } \\
\text { нювальної } \\
\text { речовини }\end{array}$ & $\begin{array}{c}\text { Середньо- } \\
\text { річний } \\
\text { вміст, } \\
\text { мг/м }{ }^{3} \\
\end{array}$ & $\begin{array}{c}\text { Середньо- } \\
\text { добові } \\
\text { ГДК, } \\
\text { мг/м } \\
\end{array}$ & 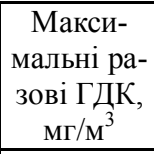 & $\begin{array}{c}\text { Макси- } \\
\text { мальний } \\
\text { вміст, } \\
\text { мг/м } \\
\end{array}$ \\
\hline Пил & 0,10 & 0,1 & 0,5 & 0,4 \\
\hline Діоксид азоту & 0,05 & 0,05 & 0,2 & 0,36 \\
\hline Сірководень & 0,001 & 0,004 & 0,008 & 0,007 \\
\hline Аміак & 0,04 & 0,05 & 0,2 & 0,52 \\
\hline Оксид вуглецю & 1,00 & 1,0 & 5,0 & 3,0 \\
\hline Діоксид сірки & 0,012 & 0,012 & 0,5 & 0,061 \\
\hline Формальдегід & 0,007 & 0,008 & 0,035 & 0,067 \\
\hline Оксид азоту & 0,03 & 0,03 & 0,4 & 0,15 \\
\hline
\end{tabular}

Викиди забруднювальних речовин в атмосферне повітря від стаціонарних джерел забруднення у Черкасах за 2017-2019 рр. змінювалися в межах від 20,107 до 24,437 тис. т (рис. 2).

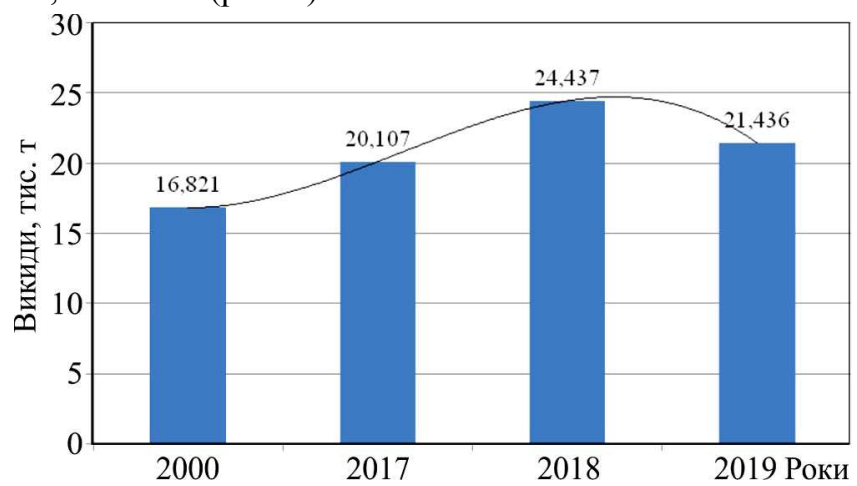

Рис. 2. Динаміка викидів забруднювальних речовин в атмосферне повітря від стаціонарних джерел забруднення м. Черкаси [29] / The dynamics of pollutants emissions from stationary sources of pollution into the atmosphere in Cherkasy [29]

За 2019 р. індекс забруднення атмосфери (далі I3А) збільшився в 1,1 раза і становив 7,22, що вважають високим рівнем забруднення атмосферного повітря (за I3А від 7 до 13) (рис. 3). Отже, в Черкасах спостерігається тенденція до збільшення рівня забруднення атмосферного повітря, що разом 3 несприятливими метеорологічними умовами спричиняє послаблення соснових деревостанів паркових насаджень міста. Проаналізувавши вміст фотосинтетичних пігментів у хвої друго- 
го року життя дерев Pinus sylvestris L. з'ясовано, що вміст хлорофілів і каротиноїдів хвої у парках "Сосновий бір" та "Обласна лікарня" вища, ніж у дерев контрольної ділянки та дерев парку "Перша міська лікарня" (табл. 3).

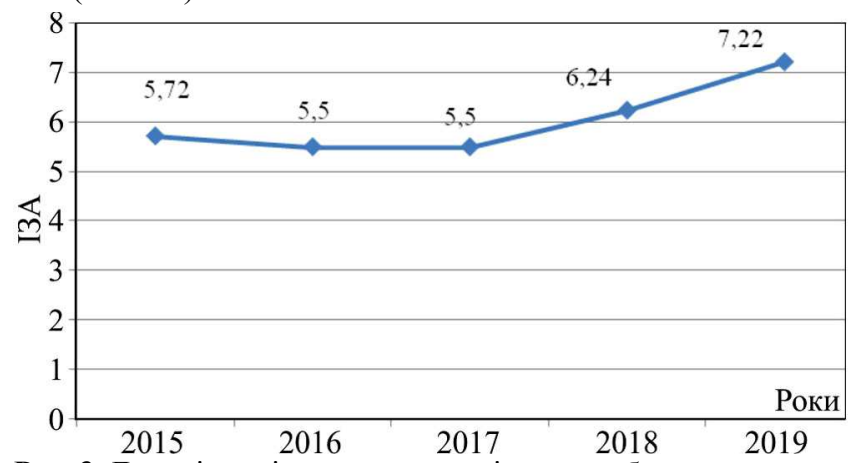

Pис. 3. Динаміка змін комплексного індексу забруднення атмосферного повітря для Черкас [29] / The dynamics of changes in the complex index of air pollution in Cherkasy [29]

Табл. 3. Вміст фотосинтетичних пігментів у хвої другого року життя дерев сосни звичайної (Pinus sylvestris L.) /

The content of photosynthetic pigments in the needles of the second year of life of Scots pine trees (Pinus sylvestris L.)

\begin{tabular}{|c|c|c|c|c|}
\hline Назва парку & $A$ хл $a$ & $A$ хл $b$ & $A$ хл $a+b$ & $A$ кар \\
\hline $\begin{array}{c}\text { Контрольна } \\
\text { ділянка }\end{array}$ & $\frac{0,74 \pm 0,03}{9,32}$ & $\frac{0,21 \pm 0,02}{8,42}$ & $\frac{0,94 \pm 0,03}{9,04}$ & $\frac{0,23 \pm 0,02}{15,34}$ \\
\hline $\begin{array}{c}\text { Сосновий } \\
\text { бір }\end{array}$ & $\frac{0,88 \pm 0,03}{4,66}$ & $\frac{0,34 \pm 0,02}{13,48}$ & $\frac{1,22 \pm 0,02}{4,65}$ & $\frac{0,29 \pm 0,01}{15,46}$ \\
\hline $\begin{array}{c}\text { Парк облас- } \\
\text { ної лікарні }\end{array}$ & $\frac{1,01 \pm 0,04}{10,55}$ & $\frac{0,40 \pm 0,05}{9,63}$ & $\frac{1,40 \pm 0,06}{11,11}$ & $\frac{0,32 \pm 0,04}{17,18}$ \\
\hline $\begin{array}{c}\text { Парк Пер- } \\
\text { шої міської } \\
\text { лікарні }\end{array}$ & $\frac{0,50 \pm 0,02}{11,45}$ & $\frac{0,20 \pm 0,02}{9,36}$ & $\frac{0,68 \pm 0,03}{8,75}$ & $\frac{0,15 \pm 0,01}{15,25}$ \\
\hline
\end{tabular}

Примітка: над рискою $-M \pm m$, під рискою $-C V, \%$.

Підвищення вмісту фотосинтетичних пігментів пояснюють тим, що досліджувані деревостани перебувають під хронічним впливом невисоких концентрацій аерополютантів, які можуть здійснювати додаткове позакореневе живлення, тому у них розвивається адаптація до таких стресогенних умов. I. I. Коршиков зазначає, що у здорових хвоїнках розвивається адаптивна специфічна реакція на стрес, тобто посилюються компенсаційні механізми, які спрямовані на відновлення фотосинтетичних реакцій в умовах розвитку хлоротичних і некротичних змін певної частини хвоїнок [19].

Інші дослідження показали, що скорочення площі листків картоплі на 10-50 \% призводить до підвищення фотосинтетичної активності на інших листках рослин [24]. Але у дерев сосни звичайної парку "Перша міська лікарня" вміст фотосинтетичних пігментів нижчий, що можна пояснити більшим впливом стресогенних чинників, а саме тим, що цей парк має меншу площу, ніж інші досліджувані парки, також перебуває під впливом значного транспортного навантаження (як автотранспорту, так і залізничного транспорту).

За результатами аналізу кореляційного зв'язку між хімічним складом атмосферних опадів (снігових вод) $\mathrm{i}$ вмістом фотосинтетичних пігментів встановлено зворотно пропорційний зв'язок між вмістом пігментів та концентрацією сульфат-йонів, нітрат-йонів, йонів амонію і прямо пропорційний зв'язок зі значеннями $\mathrm{pH}$ (табл. 4).
Табл. 4. Кореляція між деякими показниками хімічного складу атмосферних опадів і вмістом фотосинтетичних пігментів у хвої другого року життя дерев Pinus

sylvestris L. / Correlation between some indicators of chemical composition of precipitation and the content of photosynthetic pigments in the needles of the second year of life of Scots pine trees (Pinus sylvestris L.)

\begin{tabular}{|c|c|c|c|}
\hline \multicolumn{2}{|c|}{ Показник хімічного складу снігу, мг/л } & $r$ & $t_{s}$ \\
\hline \multirow{3}{*}{$\mathrm{SO}_{4}{ }^{2-}$} & хлорофіл $a$ & $-0,844$ & $6,24^{*}$ \\
\cline { 2 - 4 } & хлорофіл $b$ & $-0,762$ & $5,37^{*}$ \\
\cline { 2 - 4 } & каротиноїди & $-0,675$ & 2,02 \\
\hline \multirow{3}{*}{$\mathrm{NO}_{3}{ }^{-}$} & хлорофіл $a$ & $-0,612$ & 2,05 \\
\cline { 2 - 4 } & хлорофіл $b$ & $-0,418$ & 1,74 \\
\cline { 2 - 4 } & каротиноїди & $-0,387$ & 1,62 \\
\hline \multirow{3}{*}{$\mathrm{NH}_{4}{ }^{+}$} & хлорофіл $a$ & $-0,313$ & 1,13 \\
\cline { 2 - 4 } & хлорофіл $b$ & $-0,126$ & 0,49 \\
\cline { 2 - 4 }${ }^{*} \mathrm{pH}$ & каротиноїди & $-0,284$ & 0,37 \\
\cline { 2 - 4 } & хлорофіл $a$ & 0,642 & 2,13 \\
\cline { 2 - 4 } & хлорофіл $b$ & 0,285 & 0,74 \\
\hline
\end{tabular}

Примітка: $t_{s}$ при $t_{0,05}=2,26, n=10 ;{ }^{*}$ - значення коефіцієнта кореляції достовірні.

Але достовірний зв'язок виявився між концентрацією сульфат-йонів та вмістом хлорофілу $a$ і хлорофілу $b$, причому сила зв'язку між аналізованими параметрами є високою. Сила зв'язку між концентрацією сульфатйонів та вмістом каротиноїдів виявилася середньою. Також середню силу зв'язку зафіксовано між концентрацією нітрат-йонів та значеннями $\mathrm{pH}$ для хлорофілу $a$ і каротиноїдів, а для хлорофілу $b$ - низька; низьку силу зв'язку виявлено між концентрацією йонів амонію та вмістом досліджуваних фотосинтетичних пігментів.

Індикативною ознакою впливу стресогенних чинників є зміна відносних показників вмісту фотосинтетичних пігментів, а саме зменшення співвідношення хлорофілу $a$ до хлорофілу $b$ і збільшення відносної кількості каротиноїдів щодо хлорофілу [13, 18, 19, 23, 35].

Згідно $з$ даними табл. 5, найвищий показник співвідношення вмісту хлорофілу $a$ до хлорофілу $b-$ у хвої рослин контрольної ділянки $(3,52)$, а найнижчий - у хвої сосни звичайної "Парку Першої міської лікарні" $(2,50)$, що свідчить про інтенсивніше руйнування хлорофілу $a$ під впливом чинників міського середовища. Співвідношення вмісту хлорофілів до вмісту каротиноїдів найбільше у хвої сосни звичайної "Парку Першої міської лікарні" $(4,53)$, а в контрольній ділянці цей показник найменший $(4,09)$. Отже, такі показники є індикаторами зниження інтенсивності фотосинтетичної функції досліджуваних рослини, що призводить до зменшення їх стійкості та посилення деградаційних процесів.

Табл. 5. Відносні показники вмісту фотосинтетичних пігментів у хвої другого року життя дерев Pinus sylvestris L. / Relative indicators of the content of photosynthetic pigments in the needles of the second year of life of Scots pine trees (Pinus sylvestris L.)

\begin{tabular}{|c|c|c|c|c|}
\hline $\begin{array}{c}\text { Співвідно- } \\
\text { шення вмісту } \\
\text { пігментів }\end{array}$ & $\begin{array}{c}\text { Кон- } \\
\text { трольна } \\
\text { ділянка }\end{array}$ & $\begin{array}{c}\text { "Сосно- } \\
\text { вий бір" }\end{array}$ & $\begin{array}{c}\text { "Парк об- } \\
\text { ласної лі- } \\
\text { карні" }\end{array}$ & $\begin{array}{c}\text { "Парк Пер- } \\
\text { шої міської } \\
\text { лікарні" }\end{array}$ \\
\hline$\frac{A x л а}{A x л b}$ & 3,52 & 2,59 & 2,52 & 2,50 \\
\hline$\frac{A x л а+b}{A \kappa a p}$ & 4,09 & 4,21 & 4,37 & 4,53 \\
\hline
\end{tabular}

Фотохімічну активність хлорофілу ізольованих хлоропластів визначали за швидкістю реакції Хілла, яка $\epsilon$ 
моделлю первинних реакцій фотосинтезу. Аналіз швидкості реакції Хілла (рис. 4) показав, що максимальну фотохімічну активність хлоропластів виявлено у хвої соснових дерев контрольної ділянки, а у дерев парків вона знижена, причому найнижча фотохімічна активність хлоропластів спостерігається у хвої сосни звичайної "Парку Першої міської лікарні", що свідчить про високий рівень впливу стресогенних чинників.

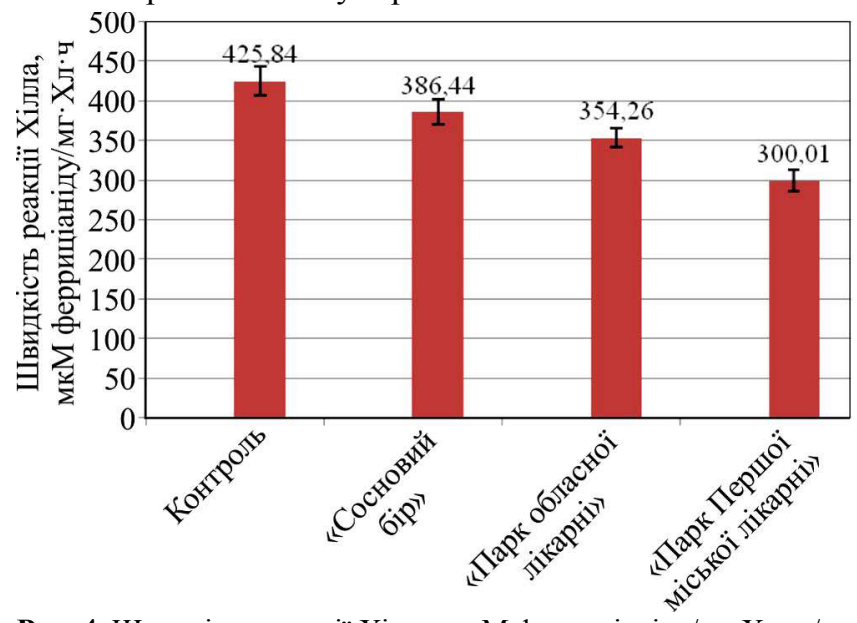

Рис. 4. Швидкість реакції Хілла, мкМ ферриціаніду/мг·Хл·ч /

The reaction rate of Hill, $\mu \mathrm{m}$ ferricyanide $/ \mathrm{mg} \cdot \mathrm{Chl} \cdot \mathrm{h}$

\section{Висновок / Conclusions}

На основі отриманих даних встановлено, що соснові деревостани досліджених парків перебувають під впливом стресових чинників міського середовища, про що свідчить зменшення співвідношення хлорофілів $a / b$, збільшення суми хлорофілів щодо каротиноїдів, пригнічення фотохімічної активності хлорофілу ізольованих хлоропластів. Але водночас у дерев парків "Сосновий бір" та "Обласна лікарня" встановлено підвищення вмісту фотосинтетичних пігментів, що є ознакою розвитку компенсаційних механізмів і формування адаптивної специфічної реакції.

У дерев сосни звичайної "Парку Першої міської лікарні" зниження концентрацій фотосинтетичних пігментів, найнижчий рівень співвідношення хлорофілів $a / b$ та найбільша сума хлорофілів щодо каротиноїдів, найнижча фотохімічна активність хлорофілу ізольованих хлоропластів свідчать про низький адаптаційний потенціал і підвищений ризик розвитку деградаційних процесів

Достовірний зворотній зв'язок між концентрацією сульфатів у снігових опадах та концентрацією хлорофілу $a\left(r=-0,844\right.$ при $\left.t_{s}=6,24>t_{0,05}=2,26\right)$ та хлорофілу $b$ $\left(r=-0,762\right.$ при $\left.t_{s}=5,37>t_{0,05}=2,26\right)$ свідчить про те, що кислотні оксиди як забруднювачі атмосферного повітря безпосередньо впливають на пригнічення фотосинтетичної функції рослин.

\section{References}

1. Adamenko, T. I. (2014). Agroclimatic zoning of the territory of Ukraine taking into account climate change. Vydavnytstvo TOV "RIABLITs. [In Ukrainian].

2. Ashraf, M. \& Harris, P. J. C. (2013). Photosynthesis under stressful environments: An overview. Photosynthetica, 51(2), 163-190. https://doi.org/10.1007/s11099-013-0021-6

3. Assadi, A., Pirbalouti, A., Malekpoor, F., Teimori, N., \& Assadi, L. (2011). Impact of air pollution on physiological and morphological characteristics of Eucalyptus camaldulensis Den. Journal of
Food, Agriculture and Environment, 9, 676-679. https://doi.org/10.1234/4.2011.2188

4. Bessonova, V. P., \& Ponomaryova, O. A. (2017). Morphometric characteristics and the content of plastid pigments of the needles of Picea pungens depending on the distance from the highways. Biosystems Diversity, 25(2), 96-101. https://doi.org/10.15421/011714

5. Chemerys, I., \& Zrazhevskyy, S. (2009). Influence of motor exhaust gases on photosynthetic function of plants. Pytannya bioindykatsiyi ta ekolohiyi, 14(2), 86-100. [In Ukrainian].

6. Didukh, Ya. P., Volvach, F. B., \& Temchenko, A. M. (1987). Ecological and coenotic characteristics of Cherkasy forest. Ukrainskyi botanichnyi zhurnal, 443(6), 68-72. [In Ukrainian].

7. Dubytskyi, O., Habriiel, H., \& Tkachuk, K. (2007). Photochemical Activity of Chloroplasts in Winter Wheat Leaves for Young Wits. Visnyk Lvivskoho universytetu. Seriia biolohichna, 43, 233240. [In Ukrainian].

8. Eckhardt, U., Grimm, B., \& Hörtensteiner, S. (2004). Recent advances in chlorophyll biosynthesis and breakdown in higher plants. Plant molecular biology, 56, 1-14. https://doi.org/10.1007/s11103-004-2331-3

9. Ecological passport of Cherkasy region in 2019. (2020). Cherkasy. [In Ukrainian].

10. Eggink, L. L., Park, H., \& Hoober, Y. K. (2001). The role of chlorophyll $b$ in photosynthesis: hypothesis. BMC Plant biology, 1, 11-17. https://doi.org/10.1186/1471-2229-1-2

11. El-Khatib, A. A., El-Shanawany, A. A., \& El-Amery, E. M. (2016). Urban tree leaf as bio-indicator for air pollution around superphosphate fertilizers plant, Upper Egypt. Journal of Ecology of Health \& Environment An International Journal, 4(2), 95-101.

12. Guidelines for the control of air pollution RD 52.04.186-89. (1991). Moscow, Hosudarstvennyi. komytet SSSR po hydrometeorolohyy, Mynysterstvo zdravookhranenyia SSSR. [In Russian].

13. Hrytsak, L. R., Herts, A. I., Nuzhyna, N. V., Cryk, M. M., Shevchenko, V. V., \& Drobyk, N. M. (2018). The influence of light regime on the growth data and pigment composition of the plant Gentiana lutea cultured in vitro. Regulatory Mechanisms in Biosystems, 9(2), 258-266. https://doi.org/10.15421/021838

14. Ilkun, G. M. (1978). Air pollutants and plants. Kiev: Naukova dumka. [In Russian].

15. Izraiel, Ju., Nazarov, I., \& Pressman, A. L. (1983). Acid rain. Leningrad: Gidrometeoizdat. [In Russian].

16. Kabashnykova, L. F. (2014). Photosynthetic apparatus and stress in plants. Mynsk: Belaruskaia navuka. [In Russian].

17. Karpenko, V. P. (2010). Photochemical activity of chloroplasts of spring barley under the action of herbicide of sulfonylurea class Granstar 75 and plant growth regulator Emistim S. Ahrobiolohiia: zb. nauk. prats, Bila Tserkva, 4(80), 16-19. [In Ukrainian].

18. Kochubei, S. M., Shevchenko, V. V., Bondarenko, O. Iu., \& Panas, Y. D. (2013). Dynamics of changes in the functional activity of the photosynthetic apparatus of pea plants caused by high-temperature stress. Dopovidi Natsionalnoi akademii nauk Ukrainy, 6, 152-156. [In Russian].

19. Korshikov, I. I. (1996). Adaptation of plants to conditions of technogenically polluted environment. Kiev: Naukova dumka. [In Russian].

20. Kreslavski, V. D., Los, D. A., Schmitt, F.-J., Zharmukhamedov, S. K., Kuznetsov, V. V., \& Allakhverdiev, S. I. (2018). The impact of the phytochromes on photosynthetic processes. Biochimica et Biophysica Acta (BBA) - Bioenergetics, 1859(5), 400-408. https://doi.org/10.1016/j.bbabio.2018.03.003

21. Kreslavsky, V. D., Zorina, A. A., Los, D. A., \& Allakhverdiev, S. I. (2013). Molekular mechanisms of stress resistance of photosynthetic machinery. Molekular stress Physiology of Plants. Rout, G. R., Das, A. B. (Eds.) Springer India, 21-51.

22. Martin, B., \& Öquist, G. (1979). Seasonal and experimentally induced changes in the ultrastructure of chloroplasts of Pinus sylvestris. Physiologia Plantarum, 46, 42-47. https://doi.org/10.1111/j.1399-3054.1979.tb03183.x

23. Meitei, M. D., Kumar, A., Prasad, M. N. V., Matec, P., Waloszek, A., Maleva, M., \& Strzalka, K. (2014). Phosynthetic pigments and 
pigment-protein complexes of aquatic plants under heavy metal stress. Photosynthetic Pigments: Chemical Structure, Biological Function and Ecology. Syktyvkar, 317-332.

24. Mokronosov, A. T., \& Ivanova, N. A. (1971). Features of the photosynthetic function during partial defoliation. Fiziologiya rastenij, 18(4), 668-676. [In Russian].

25. Murata, N., Takahashi, S., Nishiyama, Y., \& Allakhverdiev, S. (2007). Photoinhibition of photosystem II under environmental stress. Biochim Biophys Acta, 1767(6), 414-421. https://doi.org/10.1016/j.bbabio.2006.11.019.

26. Musiyenko, M. M., Parshikova, T. V., \& Slavnij, P. S. (2001). Spectrophotometric methods in the practice of physiology, biochemistry and plant ecology. Kyiv: Phytosociocenter. [In Ukrainian].

27. Nature reserve fund of Ukraine. Retrieved from: https://pzf.land.kiev.ua/pzf-obl-24.html

28. Redko, G. I., \& Shlapak, V. P. (1991). Cherkassky Bor: history, afforestation, use. Kiev: Lybid. [In Russian].

29. Regional report on the state of the environment in Cherkasy region in 2019. (2020). Cherkassy. [In Ukrainian].

30. Rusak, S. N., Varlam, Y. Y., \& Kazartseva, K. V. (2019). The ecological state of Scots pine in the urbanized northern territories. Slozhnost. Razum. Postneklassyka, 2, 13-17. https://doi.org/10.12737/article 5d4831c4b1e7f8.05899442
31. Sergejchik, S. (1990). Sulfur as a food element and pollutant. Lesnye jekosistemy $i$ atmosfernoe zagrjaznenie. Leningrad.

32. Sokhanchak, R., Lobachevska, O., \& Beshlei S. (2013). Seasonal changes at the moss complex Campylopus introflexus (Hedw.) Brid. on the top of the Nadiya mine. Visnyk Lvivskoho universytetu. Seriia biolohichna, 62, 180-187. [In Ukrainian].

33. Syvash, O. O., Mykhailenko, N. F., \& Zolotarova, O. K. (2018). Visnyk Kharkivskoho natsionalnoho ahrarnoho universytetu. Seriia Biolohiia, 3, 49-73. https://doi.org/10.35550/vbio2018.03.049

34. Timoshenko, V. F., \& Zhmurko, V. V. (2020). Photochemical activity of chloroplasts isogenic by $\mathrm{E}$ genes of soybean lines ( $\mathrm{Glyci}$ ne $\max (L$.$) Merr.) at different times of irradiation with red light.$ Visnyk Kharkivskoho natsionalnoho universytetu imeni $V$. N. Karazina. Seriia "Biolohiia", 34(34), 185-193. https://doi.org/10.26565/2075-5457-2020-34-19

35. Topchiy, N. M. (2010). Effect of heavy metals on photosynthesis. Fiziologiya i Biokhimiya kult. Rastenii, 42(2), 95-106. [In Ukrainian].

36. Wahid, A., Gelani, S., Ashraf, M., \& Foolad, M. R. (2007). Hea tolerance in plants: An overview. Environmental and Experimental Botany, 61(3), 199-223. https://doi.org/10.1016/j.envexpbot.2007.05.011

I. A. Chemerys, S. I. Kliuchka

Cherkasy State Technological University, Cherkasy, Ukraine

\section{CONTENT OF PHOTOSYNTHETIC PIGMENTS IN PINUS SYLVESTRIS L. IN THE CONDITIONS OF CHERKASY RESERVED OBJECTS}

Tree plantations of city parks, which belong to the Nature Reserve Fund of the state, are under the influence of stress factors, so the problem of their diagnosis is relevant. The photosynthetic apparatus of plants is one of the indicators of their living condition. The study tested the photosynthetic apparatus of pine needles of Scots pine in the parks-monuments of Cherkasy. In the course of the research we have revealed that the combination of temperature fluctuations and increase of average summer temperature and decrease of relative humidity of air creates conditions for droughts in Cherkasy. High levels of air pollution (pollution index is 7.22) combined with low potential for dispersion of harmful impurities in the atmosphere contribute to the weakening of pine stands in the city parks. The results of research show an increase in the concentration of chlorophyll and carotenoids of pine needles compared to the trees of the control area in such parks as Pine Forest (Ahl $a 1.2$ times; Ahl $b 1.6$ times; Akar 1.3 times) and Regional Hospital (Ahl $a$ 1.4 times; Ahl $b 1.9$ times; Akar 1.4 times). In the e of First City Hospital Park the concentration of chlorophyll $a$ and carotenoids is 1.5 times less, and chlorophyll $b$ is 1,05 times less than in control trees. Furthermore, the research established a significant correlation between the concentration of sulphates in snowfall and the concentration of chlorophyll $a\left(r=-0.844\right.$ at $\left.t_{s}=6.24>t_{0.05}=2.26\right)$ and chlorophyll $\mathrm{b}\left(r=-0.762\right.$ at $\left.t_{s}=5.37>t_{0.05}=2.26\right)$. The ratio of chlorophyll $a$ to chlorophyll $b$ in the studied trees is lower $(2.50$ 2.59) than in control trees (3.52). The research showed that the ratio of chlorophyll content to carotenoid content in the trees of the control area (4.09) wass less than in the trees of park plantations (4.21-4.53). The photochemical activity of chloroplasts of pine stands of the studied areas is found to be lower compared to the control $\left(425.84^{ \pm 18.24}\right)$ : Pine Forest Park $386.44^{ \pm 15.63}$, Regional Hospital Park 354.26 $6^{ \pm 12.34}$, and First City Hospital Park 300.01 $1^{ \pm 13.85}$. The changes in the photosynthetic apparatus of plants of Sosnovyi Bir Park and Regional Hospital Park indicate the development of an adaptive specific response to stressors of the urban environment, moreover, a decrease in all studied indicators of the Scots pine of First City Hospital Park diagnoses suppression of the photosynthetic function of stands and development processes.

Keywords: urban plantations; meteorological factors; concentrations of photosynthetic pigments; photochemical activity of chloroplasts; pine stands. 